\title{
Pathology and Pathophysiology of Atherothrombosis: Virchow's Triad Revisited
}

\author{
Atsushi Yamashita and Yujiro Asada \\ University of Miyazaki, \\ Japan
}

\section{Introduction}

In 1856, Rudolf Virchow published "Cellular pathology" based on macroscopic and microscopic observation of diseases, and described a triad of factors on thrombosis. The three components were vascular change, blood flow alteration, and abnormalities of blood constituents. Although Virchow originally referred to venous thrombosis, the theory can also be applied to arterial thrombosis, and it is considered that atherothrombus formation is regulated by the thrombogenicity of exposed plaque contents, local hemorheology, and blood factors. Thrombus formation on a disrupted atherosclerotic plaque is a critical event that leads to atherothrombosis. However, it does not always result in complete thrombotic occlusion with subsequent acute symptomatic events (Sato et al., 2009). Therefore, thrombus growth is also critical to the onset of clinical events. In spite of intensive investigation on the mechanisms of thrombus formation, little is known about the mechanisms involved in thrombogenesis or thrombus growth after plaque disruption, because thrombus is assessed with chemical or physical injury of "normal" arteries in most animal models of thrombosis.

Vascular change is an essential factor of atherothrombosis. Atherothrombosis is initiated by disruption of atherosclerotic plaque. The plaque disruption is morphologically characterized, however, the triggers of plaque disruption have not been completely understood. Tissue factor (TF) is an initiator of the coagulation cascade, is normally expressed in adventitia and variably in the media of normal artery (Drake et al., 1989). Because the atherosclerotic lesion expresses active TF, it is considered that $\mathrm{TF}$ in atherosclerotic lesion is a major determinant of vascular wall thrombogenicity (Owens \& Mackman, 2010). Therefore, atherosclerotic lesions with TF expression are indispensable for studying atherothrombosis. To examine thrombus formation on TF-expressing atherosclerotic lesions, we established a rabbit model of atherothrombosis (Yamashita et al., 2003, 2009). This allowed us to investigate the "Virchow's triad" on atherothrombosis.

Blood flow is a key modulator of the development of atherosclerosis and thrombus formation. The areas of disturbed flow or low shear stress are susceptible for atherogenesis, whereas areas under steady flow and physiologically high shear stress are resistant to atherogenesis (Malek et al., 1999). The transcription of thrombogenic or anti-thrombogenic genes is also regulated by shear stress (Cunningham \& Gotlieb, 2005). The blood flow can be altered by vascular stenosis, acute luminal change after plaque disruption, and micovascular constriction induced by distal embolism (Topol \& Yadav, 2003). The blood flow alteration after plaque disruption may affect thrombus formation. 
Blood circulates in the vessel as a liquid. This property suddenly changes after plaque disruption. The exposure of matrix proteins and TF induce platelet adhesion, aggregation and activation of coagulation cascade, resulted in platelet-fibrin thrombus formation. Clinical studies revealed increased platelet reactivity, coagulation factors, and reduced fibrinolytic activity in patients with atherothrombosis (Feinbloom \& Bauer, 2005), and that risk factors for atherothrombosis can affect these blood factors (Lemkes et al., 2010, Rosito et al., 2004). In addition, recent evidences suggest that white blood cells can influence arterial thrombus formation. It seems that abnormalities on blood factors affect thrombus growth rather than initiation of thrombus formation.

This article focuses on pathology and pathophysiology of coronary atherothrombosis. Because mechanisms of atherothrombus formation are highly complicated, we separately discuss the "Virchow's triad" on atherothrombogenesis and thrombus growth.

\section{Pathology of atherothrombosis}

Traditionally, it is considered that arterial thrombi are mainly composed of aggregated platelets because of rapid blood flow condition, and the development of platelet-rich thrombi has been regarded as a cause of atherothrombosis. However, recent evidences indicate that atherothrombi are composed of aggregated platelets and fibrin, along erythrocytes and white blood cells, and constitutively immunopositive for GPIIb/IIIa (a platelet integrin), fibrin, glycophorin A (a membrane protein expressed on erythrocytes), von Willbrand factor (VWF, a blood adhesion molecule). And neutrophils are major white blood cells in coronary atherothrombus (Nishihira et al., 2010, Yamashita et al., 2006a). GPIIb/IIIa colocalized with VWF. TF was closely associated with fibrin (Yamashita et al., 2006a). The findings suggest that VWF and/or TF contribute thrombus growth and obstructive thrombus formation on atherosclerotic lesions, and that the enhanced platelet aggregation and fibrin formation indicate excess thrombin generation mediated by TF.

Overexpression of TF and its procoagulant activity have been found in human atherosclerotic plaque, and TF-expressing cells are identified as macrophages and smooth muscle cells (SMC) in the intima (Wilcox et al., 1989). The TF activity is more prominent in fatty streaks and atheromatous plaque than in the diffuse intimal thickening in aorta (Hatakeyama et al., 1997). Thus, atherosclerotic plaque has a potential to initiate coagulation cascade after plaque disruption, and TF in the plaque is thought to play an important role in thrombus formation after plaque disruption. Interestingly, TF pathway inhibitor (TFPI), a major down regulator of TF-factor VIIa (FVIIa) complex, is also upregulated in atherosclerotic lesions (Crawley et al., 2000). In addition to endothelial cells, macrophages, medial and intimal SMCs express TFPI. These evidence suggest that imbalance between TF and TFPI contribute to vascular wall thrombogenicity.

Two major patterns of plaque disruption are plaque rupture and plaque erosion (Figure 1). Plaque rupture is caused by fibrous cap disruption, allowing blood to come in contact with the thrombogenic necrotized core, resulting in thrombus formation. Ruptured plaque is characterized by disruption of thin fibrous caps, usually less than $65 \mu \mathrm{m}$ in thickness, rich in macrophages and lymphocytes, and poor in SMCs (Virmani et al., 2000). Thus, the thinning of the fibrous cap is though to be a state vulnerable to rupture, the so-called thin-cap fibroatheroma (Kolodgie et al., 2001). However, the thin-cap fibroatheroma is not taken into 
account in the current American Heart Association classification of atherosclerosis (Stary et al., 1995). Plaque erosion is characterized by a denuded plaque surface and thrombus formation, and defined by the lack of surface disruption of the fibrous cap. Compared with plaque rupture, patients with plaque erosion are younger, no male predominance. Angiographycally, there is less narrowing and irregularity of the luminal surface in erosion. The morphologic characteristics include an abundance of SMCs and proteoglycan matrix, expecially versican and hyaluronan, and disruption of surface endothelium. Necrotic core is often absent. Plaque erosion contains relatively few macrophages and T cells compared with plaque rupture (Virmani et al., 2000). Thrombotic occlusion is less common with plaque erosion than plaque rupture, whereas microembolization in distal small vessels is more common with plaque erosion than plaque rupture (Schwartz et al., 2009). The proportions of fibrin and platelets differ in coronary thrombi on ruptured and eroded plaques. Thrombi on ruptured plaque are fibrin-rich, but those on eroded plaque are platelet-rich. TF and C reactive protein (CRP) are abundantly present in ruptured plaque, compared with eroded plaques (Sato et al., 2005). These distinct morphologic features suggest the different mechanisms in plaque rupture and erosion.

HE

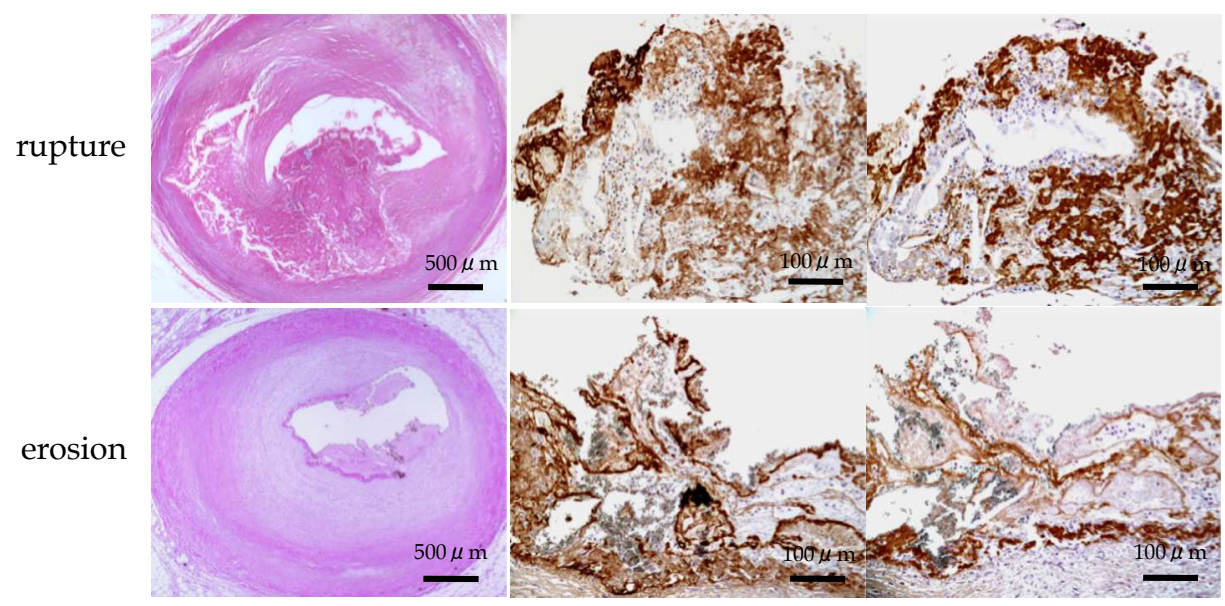

Fig. 1. Human coronary plaque rupture and erosion in patients with acute myocardial infarction.

Large necrotic core and disrupted thin fibrous cap is accompanied by thrombus formation in ruptured plaque. Eroded plaque has superficial injury of SMC-rich atherosclerotic lesion with thrombus formation. Both thrombi comprise platelets and fibrin. HE, Hematoxylin eosin stain (from Sato et al. 2005, with permission).

\section{Pathology of asymptomatic atherothrombus}

On the other hands, the disruption of atherosclerotic plaque does not always result in complete thrombotic occlusion with subsequent acute symptomatic events. The clinical studies using angioscopy have revealed that multiple plaque rupture is a frequent complication in patients with coronary atherothrombosis (Okada et al., 2011). Healed stages 
of plaque disruption are also occasionally observed in autopsy cases with or without coronary atherothrombosis (Burke et al., 2001). To evaluate the incidence and morphological characteristics of thrombi and plaque disruption in patients with non-cardiac death, Sato et al. (2009) examined 102 hearts from non-cardiac death autopsy cases and 19 from those who died of acute myocardical infarction (AMI). They found coronary thrombi in $16 \%$ of cases with non-cardiac death, and most of them developed on plaque erosion, and the thrombi were too small to affect coronary lumen (Figure 2, Table 1). The disrupted plaques in noncardiac death case had smaller lipid areas, thicker fibrous caps, and more modest luminal narrowing than those in cases with AMI. A few autopsy studies have examined the incidence of coronary thrombus in non-cardiac death. Davies et al. (1989) and Arbustini et al. (1993) found 3 (4\%) mural thrombi in 69, and 10 (7\%) thrombi in 132 autopsy cases with non-cardiac death. The all coronary thrombi from non-cardiac death were associated with plaque erosion (Arbustini et al., 1993). Although the precise mechanisms of plaque erosion remain unknown, it is possible that the superficial erosive injury is a common mechanism of coronary thrombus formation. The results suggest that plaque disruption does not always result in complete thrombotic occlusion with subsequent acute symptomatic events, that thrombus growth is critical step for the onset of clinical events, and that at least the regional factors influence the size of coronary thrombus after plaque disruption.

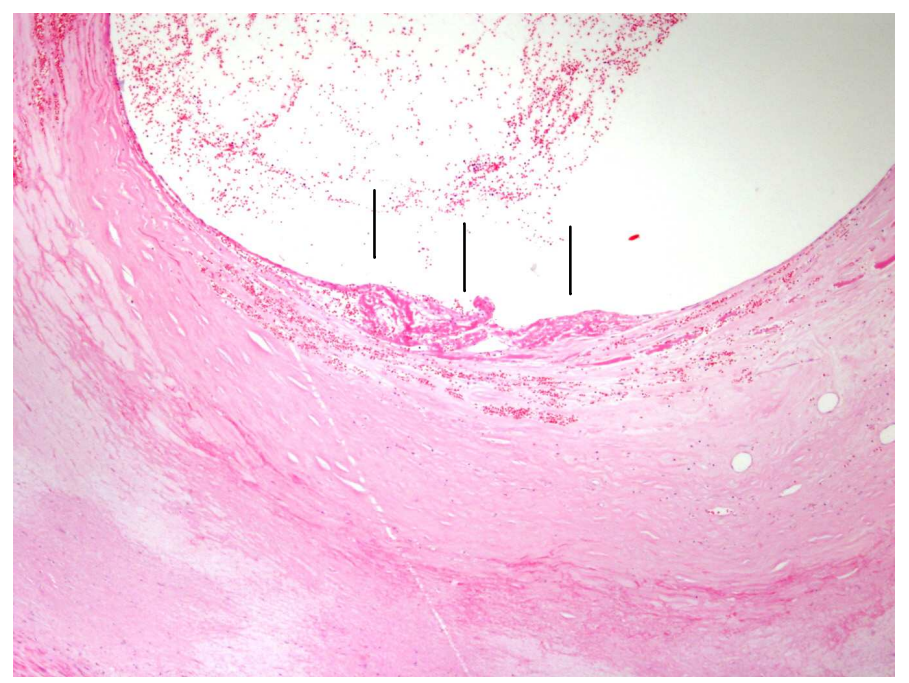

Fig. 2. Human coronary plaque erosion in patient with non-cardiac death.

\begin{tabular}{|c|c|c|c|}
\hline & $\begin{array}{c}\text { Non-cardiac death } \\
(\mathrm{n}=102)\end{array}$ & $\begin{array}{c}\text { Acute myocardial infarction } \\
(\mathrm{n}=19)\end{array}$ & P value \\
\hline Fresh thrombus & $10(10 \%)$ & $14(74 \%)$ & $<0.001$ \\
\hline erosion & $7(7 \%)$ & $4(21 \%)$ & 0.07 \\
\hline rupture & $3(3 \%)$ & $10(53 \%)$ & $<0.001$ \\
\hline Old thrombus & $6(6 \%)$ & $5(26 \%)$ & $<0.05$ \\
\hline
\end{tabular}

(From Sato et al. 2009, with permission)

Table 1. Incidence of thrombosis in non-cardiac death and acute myocardial infarction. 
The atherosclerotic lesion shows superficial erosive injury with mural thrombus (arrows). The thrombus is too small to obstruct coronary lumen and induce symptomatic event (hematoxyline eosin stain, from Sato et al. 2009, with permission).

\section{Pathophysiology of atherothrombosis}

\subsection{Triggers on plaque disruption}

As described above, atherothrombosis is initiated by plaque rupture or plaque erosion. The plaque disruption is probably affected by vascular wall change and local blood flow. Our recent study revealed that disturbed blood flow could trigger plaque erosion in rabbit femoral artery with SMC-rich plaque. We separately discuss possible factors that affect plaque rupture or plaque erosion in atherosclerotic vessels.

\subsubsection{Vascular change in plaque rupture}

The thinning and disruption of fibrous cap by metalloproteases together with local rheological forces and emotional status is likely to be involved in plaque rupture. Accumulating evidence supports a key role for inflammation in the pathogenesis of plaque rupture. The inflammatory cells that appear quite numerous in rupture-prone atherosclerotic plaques can produce enzymes degrading the extracellular matrix of the fibrous cap. Macrophages in human atheroma overexpress interstitial collagenases and gelatinases, and elastolytic enzymes. Activated T lymphocytes and macrophages can secrete interferon $\gamma$ (INF- $\gamma$ ), which inhibits collagen synthesis and induces apoptotic death of SMC (Shah, 2003). Moreover, INF- $\gamma$ can induce interleukine (IL)-18, an accelerator of inflammation. IL-18 is colocalized with INF- $\gamma$ in macrophage located at shoulder region, but not at necrotic core, and is associated with coronary thrombus formation in patients with ischemic heart disease (Nishihira et al., 2007). IL-10, an important anti-inflammatory cytokine, also is upregulated in macrophage in atherosclerotic lesion from patients with unstable angina compared with stable angina (Nishihira et al., 2006b). Heterogeneity of macrophages in atherosclerotic plaque could explain the paradoxical findings (Waldo et al., 2008). These evidences indicate that the imbalance of inflammatory pathway appear to participate in the destabilization of the plaque that triggers thrombosis in fibrous cap rupture.

Other possible trigger of plaque rupture is intraplaque hemorrhage. The frequency of previous hemorrhages is greater in coronary atherosclerotic lesions with late necrosis and thin fibrous cap than those lesions with early necrosis or intimal thickening (Kolodgie et al., 2003). Plaque hemorrhage is present in majority ( $>75 \%$ ) of acute ruptures, and in $40 \%$ of fibrous cap and thin-fibrous cap atheromas. In addition, intraplaque hemorrhage is more frequently seen in patients with AMI compared to patients with healed myocardial infarction or non-cardiac death (Virmani et al., 2003). In coronary culprit lesions obtained by directional coronary atherectomy, intraplaque hemorrhage and iron deposition were more prominent in patients with unstable angina pectoris than with stable angina pectoris. The iron deposition correlated with oxidized low density lipoprotein and thioredoxin, an antioxidant protein, and was also associated with thrombus formation (Nishihira et al., 2008b). The pathological findings imply a possible relationship among intraplaque hemorrhage, oxidative stress, and plaque instability. However, the direct evidence that links intraplaque hemorrhage to plaque instability is still lacking. 


\subsubsection{Blood flow-induced mechanical stress on plaque rupture}

Blood flow-induced mechanical stress is an essential factor of development of atherosclerosis and atherothrombosis. The low shear stress and oscillatory shear stress are both important stimuli for induction of atherosclerosis. Using a perivascular shear stress modifier in mice, Cheng et al. (2006) revealed that low shear stress induces larger lesions with vulnerable plaque phenotype (more lipids, more proteolytic enzymes, less SMCs, and less collagen) whereas vortices with oscillatory shear stress induce stable lesions. Chatzizisis et al. (2011) reported development of thin fibrous cap atheroma in coronary artery with low shear stress in pigs. In addition, the shear stress-induced changes in atherosclerotic plaque composition are modulated by chemokines. Inhibition of fractalkine, which is exclusively expressed in the low shear stress-induced atherosclerotic plaque, was reduced lipid and macrophage accumulation in the brachiocephalic arteries in mice (Cheng et al., 2007). Therefore, lower shear stress can induce atherosclerotic lesion prone to plaque rupture. Although it is well recognized that a mechanical stress triggers the disruption of fibrous cap, it remains unclear which factor is mainly responsible for the disruption of the thin fibrous cap. A variety of mechanical factors have been postulated to play a role in plaque rupture, including hemodynamic shear stress, turbulent pressure fluctuation (Loree et al., 1991), sudden increases in intraluminal pressure (Muller et al., 1989), and tensile stress concentration within the wall of the lesion. To investigate the relationship between shear stress distribution and coronary plaque rupture, Fukumoto et al. (2008) analyzed 3dimmensional intravascular ultrasound images in patients with acute coronary thrombosis by a program for calculating the fluid dynamics. The ruptured sites were located in the proximal or top portion of the plaques, and the localized high shear stress is frequently correlated with the rupture sites. This finding is inconsistent with role of low shear stress on atherogenesis. It is possible that the process of initiating plaque rupture is quite different form that of atherogenesis. On the other hand, an excessive concentration of tensile stress within the plaque may be one of the triggers of plaque rupture. When the tensile stress becomes greater than the fragility of the fibrous cap, a plaque disruption may be initiated. The tensile stress is increased by development of a lipid core, thinning of the fibrous cap (Loree et al., 1992). Cheng et al. (1993) analyzed the distribution of circumferential stress in human coronary arteries. The maximum circumferential stress in ruptured plaques was significantly higher than that in stable plaques, although plaque rupture does not always occur at the region of highest stress. These results suggest that a mechanical factor that triggers plaque rupture differ in each case and lesion.

\subsubsection{Disturbed blood flow on plaque erosion}

Although it has been postulated that erosions result from coronary vasospasm of SMC-rich plaque, the mechanisms of plaque erosion are poorly understood. Approximately $80 \%$ thrombi of plaque erosion are nonocclusive in spite of sudden coronary death (Virmani et al., 2000). Platelet rich emboli are found in $74 \%$ of patients dying suddenly with plaque erosion compared with plaque rupture (40\%). Because activated platelets release vasoconstrictive agents, such as 5-hydroxytriptamine (5-HT, serotonin) and thromboxane A2, these emboli might increase peripheral resistance leading to alteration of coronary blood flow. 5-HT can induce vasoconstriction and reduce coronary blood flow in human atherosclerotic vessels but not in normal arteries (Golino et al., 1991). 
Experimental aortic stenosis can induce acute endothelial change or damage of the normal aorta (Fry, 1968). Therefore, hemodynamic force, particularly disturbed blood flow induced by stenosis or vasoconstriction, could be a crucial factor in generating surface vascular damage and thrombosis. To address the relation between disturbed blood flow and plaque erosion, we investigated the pathological change after acute luminal narrowing in SMC-rich plaque in rabbit. The SMC-rich plaque was induced by a balloon injury of rabbit femoral artery, and expressed TF as human atherosclerotic plaques. Actually, the disturbed blood by acute vascular narrowing induced superficial erosive injury to the SMC-rich plaque at post stenotic regions in rabbit femoral arteries. Figure 3 shows microscopic images of the longitudinal section of the neointima at the post- stenotic region 15 min after vascular narrowing. The endothelial cells and SMCs at this region were broadly detached with time, and associated with platelet adhesion to the sub-endothelium. Apoptosis of endothelial cells
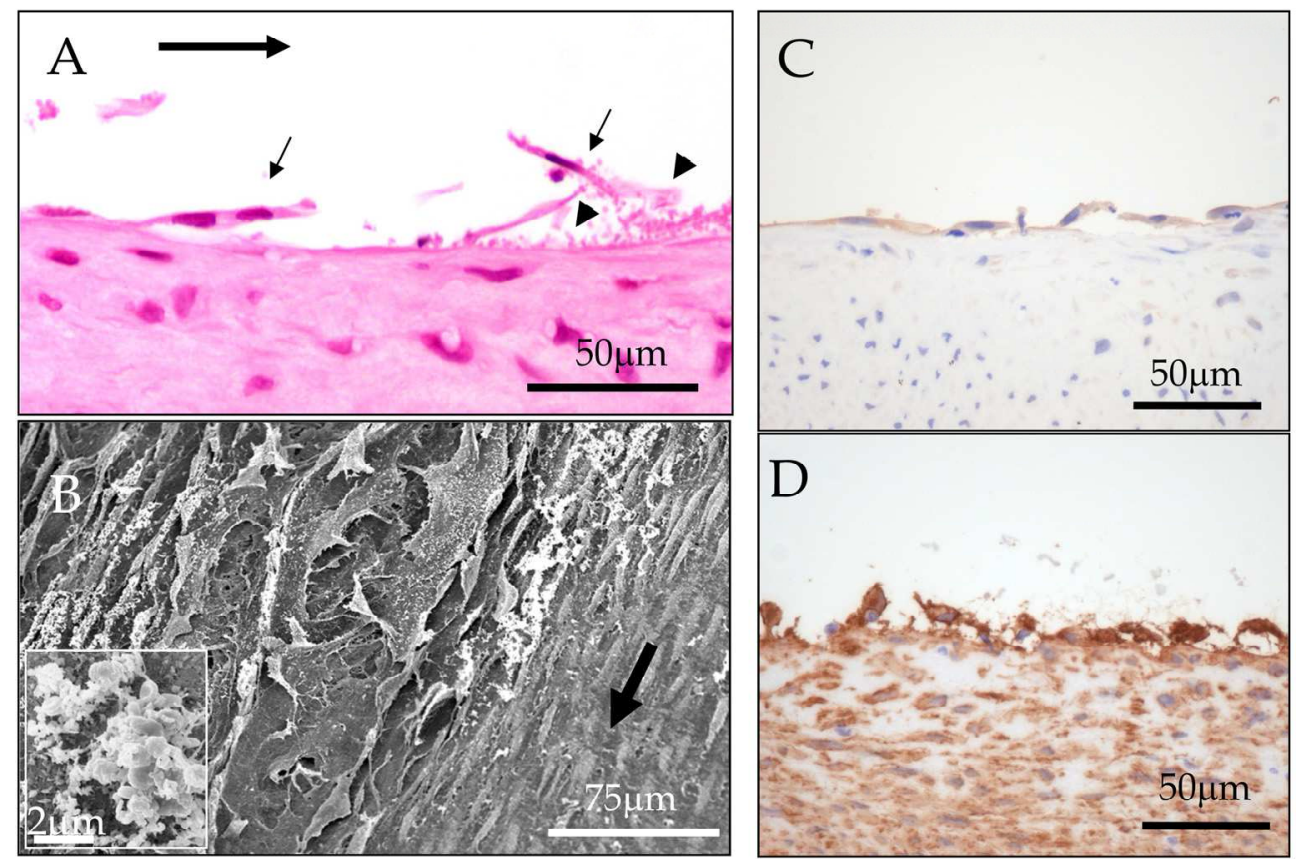

Fig. 3. Representative images of superficial erosive injury of SMC-rich plaque and thrombus formation at the post-stenotic region.

SMC-rich plaque 15 min after vascular narrowing shows endothelial detachement (small arrows) accompanies platelet adhesion (arrow heads) at $1 \mathrm{~mm}$ form vascular narrowing (A, hematoxyline eosin stain). Detachment of endothelial cells and exposure of subendothelial matrix is accompanied by platelet aggregation on the left side, and residual endothelial cell layer is present on right side (inset, high magnification of aggregated platelets) (B. scanning electron microscopy). Immunohistochemistry for VWF (C, a marker of endothelium) or smooth muscle actin (D, a marker of SMC) confirm detachment of endothelial cells and SMCs at post stenotic region (from Sumi et al. 2010, with permission). 
and superficial SMCs was also observed at the post- stenotic region within 15 minutes (Sumi et al., 2010). The vascular narrowing induced large mural thrombi which composed of platelets and fibrin, as human plaque erosion. Thus, disturbed blood flow can induce superficial erosive injury to SMC-rich plaque and thrombus formation at post stenotic region. Computational fluid simulation analysis indicated that oscillatory shear stress contributes to the development of the erosive damage to the plaque (Sumi et al., 2010). Although direct clinical evidence has not yet supported the notion that coronary artery vasospasm plays a role in plaque erosion, the superficial erosive injury of SMC-rich plaque by disturbed blood flow is similar to those of human plaque erosion (Sato et al., 2005). And, platelet and blood coagulation in coronary circulation are activated after vasospastic angina (Miyamoto et al. 2001, Oshima et al., 1990). Therefore, these evidence suggest that an acuteonset disturbed blood flow due to vasoconstriction could trigger plaque erosion. Hemodynamic factors could play an important role in development of plaque erosion.

\subsection{Virchow's triads on thrombus growth}

As described above, plaque disruption does not always result in complete thrombotic occlusion. Thrombus growth is considered critical to the onset of clinical events. Although thrombus formation is regulated by the vascular wall thrombogenicity, local blood flow, and blood contents, their contribution to thrombus growth has not been clearly defined. We separately discuss three factors that affect thrombus growth in atherosclerotic vessels.

\subsubsection{Vascular factors on thrombus growth}

Most fundamental difference between normal artery and atherosclerotic artery is presence of abundant active TF in atherosclerotic lesions (Hatakeyama et al., 1997, Wilcox et al., 1989). It seems that vascular wall $\mathrm{TF}$ contribute to thrombus size/propagation on atherosclerotic lesions. However, recent studies indicate that a small amount of TF is detectable in the blood and is capable of supporting clot formation in vitro. Plasma TF levels are elevated in patients with unstable angina and AMI and correlate with adverse outcomes (Mackman, 2004). Therefore, it is still controversial whether vascular wall and/or blood-derived TF support thrombus propagation. Hematopoietic cell-derived, TF-positive microparticles contributed to laser injury-induced thrombosis in the microvasculature of mouse cremaster muscle (Chou et al. 2004). In contrast, vascular smooth muscle-derived TF contributed to $\mathrm{FeCl}_{3}$ induced thrombosis in mouse carotid artery (Wang et al., 2009). We investigated whether plaque and/or blood TF contribute to thrombus formation in rabbit femoral artery with or without atherosclerotic lesions. The atherosclerotic lesions in rabbit femoral arteries were induced by a $0.5 \%$ cholesterol diet and balloon injury, and showed TF expression and increased procoagulant activity compared with normal femoral arteries (Figure 4). Balloon injury of the atherosclerotic plaque induced thrombin-dependent large platelet-fibrin thrombi. In contrast, balloon injury of normal femoral artery induced thrombin-independent small platelet thrombi (Figure 5). Moreover, whole blood coagulation in the rabbits was not affected by blood TF inhibition with a TF antibody even in hyperlipidemic condition (Yamashita et al., 2009). Therefore, at least, atherosclerotic plaque-derived TF might contribute to activation of intravascular coagulation cascade and thrombus size/propagation on atherosclerotic lesions. 

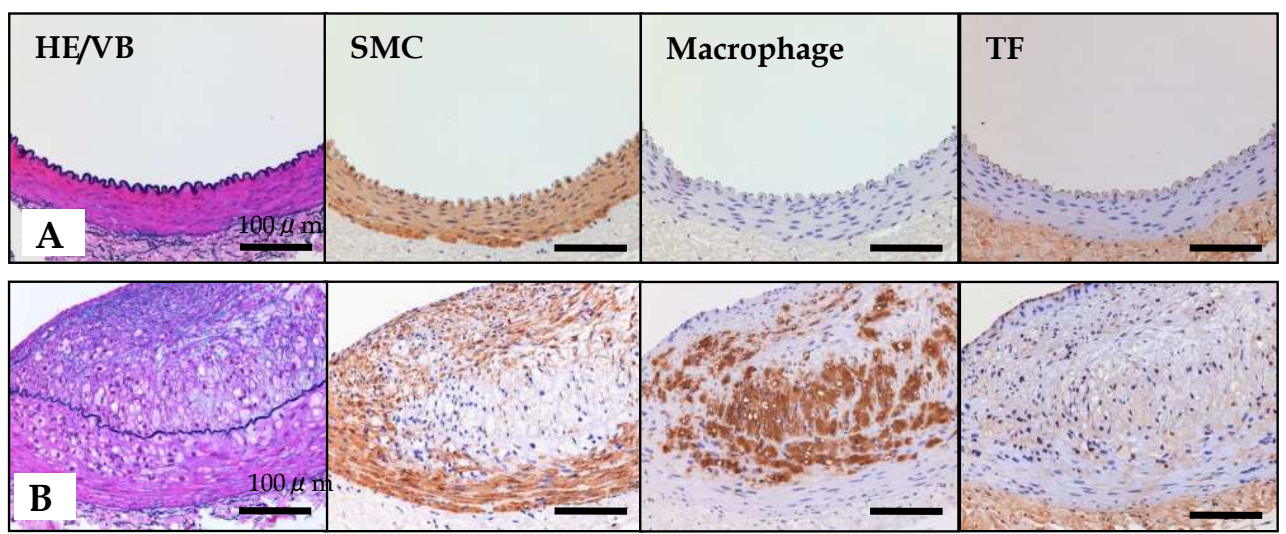

Fig. 4. Histological images of rabbit femoral arteries.

Representative immunohistochemical microphotographs of normal (A) and balloon-injured femoral artery at 3 weeks after injury under $0.5 \%$ cholesterol diet (B). Atherosclerotic lesion composed of SMCs and macrophages develops in injured artery. TF expression is present in the lesion and adventitia of both arteries. HE/VB, hematoxyline eosin/Victoria blue stain (From Yamashita et al. 2009, with permission).

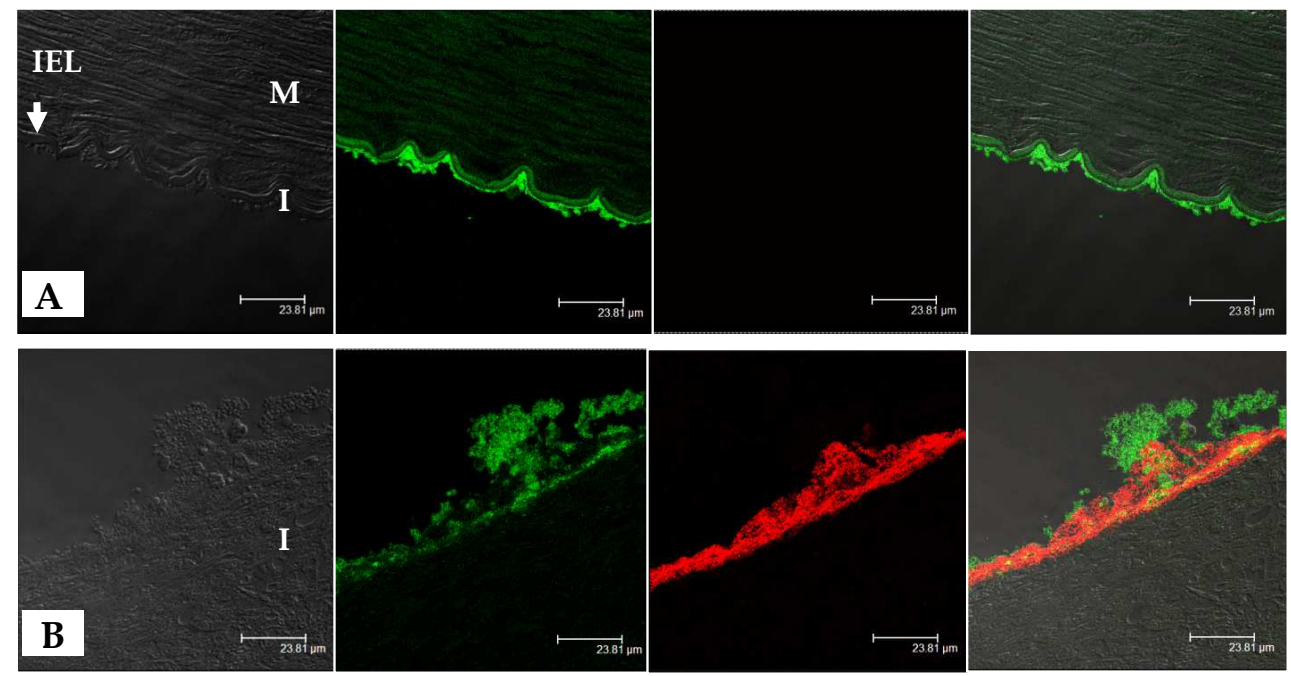

Fig. 5. Immunofluorescence images of thrombus on rabbit femoral artery.

Representative immunofluorescent microphotographs of thrombi 15 minutes after balloon injury of normal femoral artery and of atherosclerotic plaque under $0.5 \%$ cholesterol diet.

Rows show differential interference contrast images, images stained with fluorescein isothiocyanate-labeled GPIIb/IIIa (green), Cy3-labeled fibrin (red), and merged immunofluorescent images. Areas with colocalized factors are stained yellow. The thrombi on normal intima is composed of small aggregated platelet (A), while the thrombi on atherosclerotic plaque is large, and composed of platelet and fibrin (B). I, intima; M, media; IEL, internal elastic lamina. (From Yamashita et al. 2009, with permission). 
Several factors can influence TF expression in plaques and atherothrombus formation after plaque disruption. CRP is an inflammatory acute-phase reactant that has emerged as a powerful predictor of cardiovascular disease (Ridker, 2007). CRP is localized in atherosclerotic plaques and is more in thrombotic plaques than non-thrombotic ones (Ishikawa et al., 2003, Sun et al., 2005). The findings imply that CRP is implicated in atherothrombogenesis. To address this issue, CRP-transgenic rabbits were generated, because as human CRP, CRP in rabbits but not in mice works as an acute-phase reactant during inflammation (Koike et al., 2009). In the rabbits, CRP was overexpressed in livers and circulated in blood and deposited in the both SMC-rich and macrophage-rich atherosclerotic lesions. The thrombus size on SMC-rich plaque or macrophage-rich plaque after balloon injury was significantly increased in CRP-transgenic rabbits as compared with wild nontransgenic rabbits (Figure 6). TF expression and its acivity in the plaques were significantly increased in CRP-transgenic rabbits. The degree of CRP deposition correlated with TF expression in plaques and thrombus size on injured plaques (Matsuda et al., 2011). On the

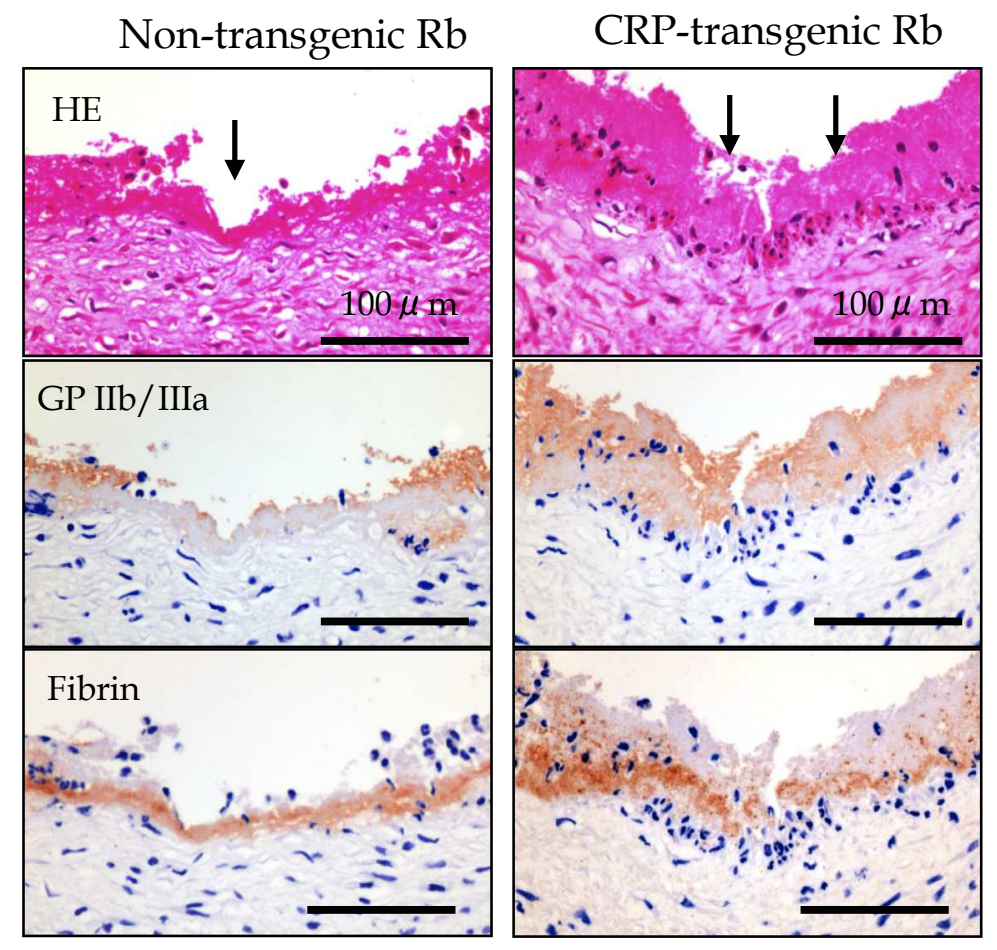

Fig. 6. Thrombus formation on SMC-rich plaque in CRP-transgenic or non-transgenic rabbit femoral artery.

The images show thrombus formation on SMC-rich plaque (arrows) $15 \mathrm{~min}$ after balloon injury of rabbit femoral arteries. The thrombus size is increased in CRP-transgenic rabbits as compared with non-transgenic rabbit. Immunopositive areas for GPIIb/IIIa and fibrin also increase in CRP-transgenic rabbit (from Matsuda et al. 2011, with permission). 
other hand, the CRP overexpression did not enhance atherosclerosis induced by hyperchoresterol diets (Koike et al., 2009). CRP localized in atherosclerotic plaques might enhance vascular wall thrombogenicity and thrombus formation after plaque disruption rather than atherogenesis.

\subsubsection{Altered blood flow on thrombus growth}

Blood flow is a key modulator of thrombus growth. Clinical studies revealed an alteration of coronary blood flow in patients with ischemic heart diseases. Marzilli et al. (2000) reported an approximate $80 \%$ reduction in coronary blood flow during ischemia in patients with unstable angina. An autopsy study reported that intramyocardial microemboli were frequently present in sudden coronary death patients (Schwartz et al. 2009). Distal microvascular embolism and/or vasoconstriction could affect blood flow alteration and thrombus formation and growth at the culprit lesions (Erbel \& Heusch, 2000). To assess the issue, we examined the effects of the blood flow reduction to thrombus formation in our animal model. Blood flow reduction $(>75 \%)$ promoted the growth of thrombus, a mixture of platelets and fibrin, on atherosclerotic lesion, which grew to occlusive one. The flow reduction also induced thrombus formation on normal arteries, but the thrombi were very small and composed only of platelets (Yamashita et al. 2004). Therefore, blood flow reduction associated with increased vascular wall thrombogenecity is considered to contribute thrombus growth. We also demonstrated an important role of 5- $\mathrm{HT}_{2 \mathrm{~A}}$ receptor on platelets and SMCs in this process via platelet aggregation and thrombogenic vasoconstriction (Nishihira et al., 2006a, 2008a).

In addition to distal vascular resistance, disturbed blood flow by acute vascular narrowing promotes thrombus growth at post stenotic regions. As described above, vascular narrowing of rabbit femoral artery induced superficial erosive injury to SMC-rich plaque at post stenotic regions. The thrombi consisted of a mixture of aggregated platelets and a considerable amount of fibrin. The whole blood hemostatic parameters in the rabbits was not changed after vascular narrowing or anti-rabbit TF antibody treatment, which evidence indicates that TF derived from eroded plaque rather than circulating TF plays an important role in fibrin generation and thrombus growth (Sumi et al. 2010).

The rheological effect on thrombus growth may be partly explained by a shear gradientdependent platelet aggregation mechanism. Using in vitro and in vivo stenotic microvessels and imaging systems, Nesbitt et al. (2009) revealed a shear gradient-dependent platelet aggregation process which is preceded by soluble agonist-dependent aggregation. Shear microgradient at post stenosis region or down stream face of thrombi induced stable platelets aggregates, and the shear microgradients directly influenced the platelet aggregation size. This process required ligand binding to integrin aIIb $\beta 3$, transient $\mathrm{Ca}^{2+}$ flux, but did not required global platelet shape change or soluble agonists. The findings suggest that platelets principally use a biomechanical platelet aggregation mechanism in early phase of platelet adhesion and aggregation. Vessel and/or thrombus geometry itself may promote thrombus formation.

\subsubsection{Blood factors on thrombus growth}

As described above, platelet is a major cellular component in coronary thrombus, and platelets play an important role in growing phase of thrombus formation, as well as initial 
phase of thrombus formation. Adhesion molecules and its receptors on platelets are essential for thrombus formation, because these molecules support platelet tethering, firm adhesion, aggregation and platelet recruitment to thrombus surface. VWF is a large, multimeric, plasma protein that undergoes a conformational change when bound to matrix under permit its binding to GPIba. Recent studies in vitro and in vivo showed that platelet recruitment on thrombus surface was primary mediated by VWF and GPIba on flowing platelets (Bergmeier et al. 2006, Kulkuni et al. 2000). We demonstrated that a large amount of VWF was localized in coronary thrombi in patients with AMI (Nishihira et al., 2010, Yamashita et al., 2006a), and that monoclonal antibody against VWF A1 domain, which interacts platelet GPIba, significantly suppressed formation of platelet-fibrin thrombi and completely inhibited occlusive thrombus formation in rabbit atherosclerotic lesions (Yamashita et al., 2003, 2004). These findings indicated a crucial role of VWF in thrombus growth via platelet recruitment. The multimer size of VWF can affect thrombus size and is regulated by a plasma protease, a disintegrin and metalloprotease with a thrombospondin type 1 motif 13 (ADAMTS-13). A deficiency of ADAMTS-13 activity causes an increased level of circulating ultralarge VWF multimers, and correlates with the onset of the general thrombotic disease, thrombotic thrombocytopenic purpura (TTP). A clinical evidence suggested dysregulation of VWF multimer size in AMI patient. The ratio of VWF/ADAMTS-13 antigen was higher in patients with AMI than in those with stable angina pectris, and there was a inverse correlation between plasma VWF antigen and ADAMTS-13 activity in AMI patients (Kaikita et al. 2006). The ADAMTS-13 closely localized with VWF in fresh coronary thrombi from AMI patients (Moriguchi-Goto et al., 2009). A reducing ADAMTS-13 activity by monoclonal antibody against distintegrin-like domain enhanced platelet thrombus growth on immobilized type I collagen at a high shear rate $\left(1500 S^{-1}\right)$ and platelet-fibrin thrombus formation on injured atherosclerotic lesion of rabbit femoral arteries (Moriguchi-Goto et al., 2009). The study also showed cleavage of large sized VWF multimer during platelet thrombus formation under a high shear rate. The VWFcleaving site by ADAMTS-13 localized on the surface of platelet thrombus, and the ADAMTS-13 activity was shear dependent manner (Shida et al. 2008). Thus, ADAMTS-13 may work at the site of ongoing thrombus generation and limit thrombus growth.

The recent studies in vitro showed various blood cells, not only monocytes but also neutrophils, eosinophils, and even if platelets, can synthesize TF. Although there is much on debate on the TF expression in blood cells, it is likely that monocytes are the only blood cells that synthesize and express TF (Østerud, 2010). A related topic is contribution of microparticles (MPs) to thrombus formation. MPs are small fragments of membrane-bound cytoplasm that are shed from the surface of an activated or apoptotic cells (Blann et al. 2009). The procoagulant activity of MPs is increased with the exposure of phosphatidylserine and the presence of TF. In fact, MPs have significantly elevated in acute coronary syndrome and ischemic strokes (Geiser et al. 1998, Singh et al. 1995). However, it is still unclear whether the elevated levels of MPs are a cause or consequence of atherothrombosis. Moreover, our animal studies did not support the role of blood-derived TF in atherothrombus formation as described above. Future studies are required to clarify contribution of blood derived TF and/or MPs to thrombus propagation on atherosclerotic lesions.

Among the white blood cells, neutrophils are mostly found in coronary thrombus in patients with AMI, and CD34 positive leukocytes are also found in the thrombus (Nishihira et al., 2010). Recent evidences revealed neutrophils and endothelial progenitor cells influence thrombus growth. Neutrophils can positively or negatively affect thrombus 
formation by degradation of coagulation or fibrinolysis factors and promoting platelet function (Kornecki et al., 1988, Moir et al., 2002). Inhibition of interaction between p-selectin and p-selectin glycoprotein ligand 1 reduced fibrin formation in vivo (Palabrica et al., 1992). These adhesion molecules have been implicated in recruitment of leukocytes and leukocyte MPs to thrombi (Vandendries et al., 2004). To reveal the neutrophil-mediated procoagulant mechanisms, Massberg et al. (2010) investigated thrombus formation using neutrophil elastase and cathepsin G deficient mice. Proteolysis of TFPI by these proteases enhanced fibrin and thrombus formation after $\mathrm{FeCl}_{3}$-induced vessel injury. In addition, activated platelets by collagen accelerated nucleosome externalization by neutrophils. The neutrophilderived externalized nucleosomes can form neutrophil extracellular traps that provide a scaffold for platelets and red blood cells and histone 3/4 can induce platelet aggregation (Fuchs et al., 2010). On the other hands, neutrophil elastase has fibriolytic potential, and there is significant correlation between neutrophil elastase-digested fibrin and leukocyte content in human atherothrombi (Rábai et al., 2010). Zeng et al. (2002) investigated contribution of polymorphonuclear leukocytes (PMNs) to fibrinolysis in vivo using plasminogen deficient mice. The PMNs accumulated within the thrombi by 6 hours after $\mathrm{FeCl}_{3}$-induced vessel injury and peaked at 24 hours. There were no significant differences between the PMNs from plasminogen deficient mice and wild type mice within the 6 hour after thrombus formation, whereas there was significant greater retention of PMNs within the thrombus over 24 hours after thrombus formation. PMNs from both mice showed fibrinolytic activity, but the degradation products were a distinct pattern. Therefore, it is possible that neutrophils works as positive or negative regulator of early or late phase of thrombus formation, respectively.

Endothelial progenitor cells (EPC) contributes to angiogenesis and wound healing (Asahara et al., 1997), and the number of EPCs in blood is associated with cardiovascular risk (Hill et al., 2003). The mechanisms that regulate mobilization, migration, and differentiation of EPCs and their homing to sites of vascular injury are complex and involve several mediators and receptors, such as P-selectin glycoprotein ligand-1, CXC chemokine, and integrins (Chavakis et al., 2005, Massberg et al., 2006). Interaction of thrombus contents and EPCs influences their mobilization and differentiation to mature endothelial cells during vascular injury (de Boer HC et al., 2006). Abou-Saleh et al. (2009) reported that human peripheral blood mononuclear cell derived EPCs bound platelets via p-selectin and inhibit platelet activation, aggregation, and adhesion to collagen in vitro, and that injection of these EPCs reduced thrombus formation after $\mathrm{FeCl}_{3}$-induced vessel injury of mouse carotid arteries.

Other possible mechanism contributing thrombus propagation in vivo is intrinsic coagulation pathway. The intrinsic coagulation pathway is initiated when coagulation factor XII (FXII) comes into contact with negatively charged surfaces in a reaction involving the plasma proteins, high molecular mass kininogen and plasma kallikrein. Factor XI (FXI) is activated by activated FXII, thrombin, and activated XI. Feedback activation of FXI by thrombin promotes further thrombin generation in vitro (Gailani \& Broze, 1991). FXI was present in platelet-fibrin thrombus induced balloon injury of atherosclerotic lesion in rabbits, and anti-FXI antibody reduced thrombus growth without prolonging bleeding (Yamashita et al., 2006b). FXI plays an important role in thrombus growth via further thrombin generation. On the other hand, there are conflicts of evidence that FXII supports arterial thrombus growth. FXII deficient mice were resistant to thrombotic occlusion after $\mathrm{FeCl}_{3}$ induced vessel injury of carotid arteries (Cheng $Q$ et al., 2010). However, a clinical study demonstrated an inverse relationship between FXII level and risk of myocardial 
infarction (Doggen et al., 2006). Moreover, inhibition of FXII did not change platelet aggregation and fibrin formation on atherosclerotic plaque surface under flow in vitro. The effect of FXII on coagulation became obvious only absence of TF (Reininger et al., 2010).

\section{Conclusion}

More than 150 years ago, Virchow described the mechanims of thrombus formation. It has still remained as a fundamental theory of thrombus formation. To date, pathological and experimental studies have clarified the mechanisms of atherothrombus formation. The thrombus formation is initiated by plaque rupture and plaque erosion. Among the Virchow's triad, vascular and rheological factors are responsible for plaque rupture. Disruption of thin fibrous cap atheroma triggers plaque rupture. On the other hand, disturbed blood by acute luminal change can trigger plaque erosion to SMC-rich plaque. Pathological findings of human atherothrombosis suggest that thrombus growth rather than plaque disruption is a critical step for the onset of cardiovascular events, and that simultaneous activation of coagulation cascade and platelets play an important role in thrombus formation after plaque disruption. All three factors contribute to atherothrombus growth. Our rabbit model of atherothrombosis revealed that excess thrombin generation mediated by plaque TF contribute to large plate-fibrin thrombus formation on atherosclerotic lesion, and that disturbed flow condition after plaque disruption promote thrombus growth. Recent evidence suggests that leukocytes influence arterial thrombus formation as well as platelet and coagulation/fibrinolysis factors. Differences between hemostasis and thrombus growth may shed light on a novel anti-atherothrombogic drug with a wide safety margin.

\section{Acknowledgement}

The work is supported in part by Grants-in-Aid for Scientific Research in Japan (No.23790410), Mitsubishi Pharma Research Foundation, and Integrated Research Project for Human and Veterinary Medicine.

\section{References}

Abou-Saleh, H., Yacoub, D., Théorêt, JF., Gillis, MA., Neagoe, PE., Labarthe, B., Théroux, P., Sirois, MG., Tabrizian, M., Thorin, E., \& Merhi, Y. (2009). Endothelial progenitor cells bind and inhibit platelet function and thrombus formation. Circulation, Vol.120, No.22, pp.2230-2239.

Arbustini, E., Grasso, M., Diegoli, M., Morbini, P., Aguzzi, A., Fasani, R., \& Specchia, G. (1993). Coronary thrombosis in non-cardiac death. Coron Artery Dis, Vol.4, No.9, pp.751-759.

Asahara, T., Murohara, T., Sullivan, A., Silver, M., van der Zee, R., Li, T., Witzenbichler, B., Schatteman, G., \& Isner, JM. (1997). Isolation of putative progenitor endothelial cells for angiogenesis. Science. Vol.275, No.5302, pp.964-967.

Bergmeier, W., Piffath, CL., Goerge, T., Cifuni, SM., Ruggeri, ZM., Ware, J., \& Wagner, DD. (2006). The role of platelet adhesion receptor GPIbalpha far exceeds that of its main ligand, von Willebrand factor, in arterial thrombosis. Proc Natl Acad Sci U S A. Vol.103, No.45, pp.16900-16905. 
Blann, A., Shantsila, E., \& Shantsila, A. (2009). Microparticles and arterial disease. Semin Thromb Hemost. Vol.35, No.5, pp.488-496.

Burke, AP., Kolodgie, FD., Farb, A., Weber, DK., Malcom, GT., Smialek J, \& Virmani R. (2001). Healed plaque ruptures and sudden coronary death: evidence that subclinical rupture has a role in plaque progression. Circulation, Vol.103, No.7, pp.934-940.

Chatzizisis, YS., Baker, AB., Sukhova, GK., Koskinas, KC., Papafaklis, MI., Beigel, R., Jonas, M., Coskun, AU., Stone, BV., Maynard, C., Shi, GP., Libby, P., Feldman, CL., Edelman, ER., \& Stone, PH. (2011). Augmented expression and activity of extracellular matrix-degrading enzymes in regions of low endothelial shear stress colocalize with coronary atheromata with thin fibrous caps in pigs. Circulation, Vol.123, No.6, pp.621-630.

Chavakis, E., Aicher, A., Heeschen, C., Sasaki, K., Kaiser, R., El Makhfi, N., Urbich, C., Peters, T., Scharffetter-Kochanek, K., Zeiher, AM., Chavakis, T., \& Dimmeler, S. (2005). Role of beta2-integrins for homing and neovascularization capacity of endothelial progenitor cells. J Exp Med, Vol.201, No.1, pp.63-72Chou, J., Mackman, N., Merrill-Skoloff, G., Pedersen, B., Furie, BC., \& Furie, B. (2004). Hematopoietic cell-derived microparticle tissue factor contributes to fibrin formation during thrombus propagation. Blood, Vol.104, No.10, pp.3190-3197.

Cheng, C., Tempel, D., van Haperen, R., van der Baan, A., Grosveld, F., Daemen, MJ., Krams, R., \& de Crom, R. (2006). Atherosclerotic lesion size and vulnerability are determined by patterns of fluid shear stress. Circulation, Vol.113, No.23, pp.2744-2753.

Cheng, C., Tempel, D., van Haperen, R., de Boer, HC., Segers, D., Huisman, M., van Zonneveld, AJ., Leenen, PJ., van der Steen, A., Serruys, PW., de Crom, R., \& Krams, R. (2007). Shear stress-induced changes in atherosclerotic plaque composition are modulated by chemokines. J Clin Invest, Vol.117, No.3, pp.616-626.

Cheng, GC., Loree, HM., Kamm, RD., Fishbein, MC., \& Lee, RT. (1993). Distribution of circumferential stress in ruptured and stable atherosclerotic lesions. A structural analysis with histopathological correlation. Circulation, Vol.87, No.4, pp.1179-1187.

Cheng, Q., Tucker, EI., Pine, MS., Sisler, I., Matafonov, A., Sun, MF., White-Adams, TC., Smith, SA., Hanson, SR., McCarty, OJ., Renné, T., Gruber, A., \& Gailani, D. (2010). A role for factor XIIa-mediated factor XI activation in thrombus formation in vivo. Blood. Vol.116, No.19, pp.3981-3989.

Chou, J., Mackman, N., Merrill-Skoloff, G., Pedersen, B., Furie, BC., \& Furie, B. (2004). Hematopoietic cell-derived microparticle tissue factor contributes to fibrin formation during thrombus propagation. Blood, Vol.104, No.10, pp.3190-3197.

Crawley, J., Lupu, F., Westmuckett, AD., Severs, NJ., Kakkar, VV., \& Lupu, C. (2000). Expression, localization, and activity of tissue factor pathway inhibitor in normal and atherosclerotic human vessels. Arterioscler Thromb Vasc Biol, Vol.20, No.5, pp.1362-1373.

Cunningham, KS., \& Gotlieb, AI. (2005). The role of shear stress in the pathogenesis of atherosclerosis. Lab Invest, Vol.85, No.1, pp.9-23.

Davies, MJ., Bland, JM., Hangartner, JR., Angelini, A., \& Thomas, AC. (1989). Factors influencing the presence or absence of acute coronary artery thrombi in sudden ischaemic death. Eur Heart J, Vol.10, No.3, pp.203-208.

Doggen, CJ., Rosendaal, FR., \& Meijers, JC. (2006). Levels of intrinsic coagulation factors and the risk of myocardial infarction among men: Opposite and synergistic effects of factors XI and XII. Blood, Vol.108, No.13, pp.4045-4051. 
Drake, TA., Morrissey, JH., \& Edgington, TS. (1989). Selective cellular expression of tissue factor in human: Implications for disorders of hemostasis and thrombosis. Am J Pathol, Vol.134, No.5, pp.1087-1097

de Boer, HC., Verseyden, C., Ulfman, LH., Zwaginga, JJ., Bot, I., Biessen, EA., Rabelink, TJ., \& van Zonneveld, AJ. (2006). Fibrin and activated platelets cooperatively guide stem cells to a vascular injury and promote differentiation towards an endothelial cell phenotype. Arterioscler Thromb Vasc Biol, Vol.26, No.7, pp.1653-1659.

Erbel, R., \& Heusch, G. (2000). Coronary microembolization. J Am Coll Cardiol, Vol.36, No.1, pp.22-24.

Feinbloom D, \& Bauer KA. (2005). Assessment of hemostatic risk factors in predicting arterial thrombotic events. Arterioscler Thromb Vasc Biol, Vol.25, No.10, pp.2043-53.

Fry, DL. (1968). Acute vascular endothelial changes associated with increased blood velocity gradients. Circ Res. Vol.22, No.2, pp.165-197.

Fuchs, TA., Brill, A., Duerschmied, D., Schatzberg, D., Monestier, M., Myers, DD, Jr, Wrobleski, SK., Wakefield, TW., Hartwig, JH., \& Wagner, DD. (2010). Extracellular DNA traps promote thrombosis. Proc Natl Acad Sci U S A. Vol.107, No.36, pp.1588015885.

Fukumoto, Y., Hiro, T., Fujii, T., Hashimoto, G., Fujimura, T., Yamada, J., Okamura, T., \& Matsuzaki, M. (2008). Localized elevation of shear stress is related to coronary plaque rupture: a 3-dimensional intravascular ultrasound study with in-vivo color mapping of shear stress distribution. J Am Coll Cardiol, Vol.51, No.6, pp.645-650.

Gailani, D., \& Broze, GJ Jr. (1991). Factor XI activation in a revised model of blood coagulation. Science, Vol.253, No.5022, pp.909-912.

Geiser, T., Sturzenegger, M., Genewein, U., Haeberli, A., \& Beer, JH. (1998). Mechanisms of cerebrovascular events as assessed by procoagulant activity, cerebral microemboli, and platelet microparticles in patients with prosthetic heart valves. Stroke, Vol.29, No.9, pp.1770-1777.

Golino, P., Piscione, F., Willerson, JT., Cappelli-Bigazzi, M., Focaccio, A., Villari, B., Villari, B., Indolfi, C., Russolillo, E., Condorelli, M., \& Chiariello, M. (1991). Divergent effects of serotonin on coronary-artery dimensions and blood flow in patients with coronary atherosclerosis and control patients. N Engl J Med, Vol.324, No.10, pp.641-648.

Hatakeyama, K., Asada, Y., Marutsuka, K., Sato, Y., Kamikubo, Y., \& Sumiyoshi A. (1997). Localization and activity of tissue factor in human aortic atherosclerotic lesions. Atherosclerosis, Vol.133, No.2, pp.213-219.

Hill, JM., Zalos, G., Halcox, JP., Schenke, WH., Waclawiw, MA., Quyyumi, AA., \& Finkel, T. (2003). Circulating endothelial progenitor cells, vascular function, and cardiovascular risk. N Engl J Med, Vol.348, No.7, pp.593-600.

Ishikawa, T., Hatakeyama, K., Imamura, T., Date, H., Shibata, Y., Hikichi, Y., Asada, Y., \& Eto, T.(2003). Involvement of C-reactive protein obtained by directional coronary atherectomy in plaque instability and developing restenosis in patients with stable or unstable angina pectoris. Am J Cardiol. Vol.91, No.3, pp.287-292.

Kaikita, K., Soejima, K., Matsukawa, M., Nakagaki, T., \& Ogawa, H. (2006). Reduced von Willebrand factor-cleaving protease (ADAMTS13) activity in acute myocardial infarction. J Thromb Haemost. Vol.4, No.11, pp.2490-2493.

Koike, T., Kitajima, S., Yu, Y., Nishijima, K., Zhang, J., Ozaki, Y., Morimoto, M., Watanabe, T., Bhakdi, S., Asada, Y., Chen, YE., \& Fan, J. (2009). Human C-reactive protein does not promote atherosclerosis in transgenic rabbits. Circulation, Vol.120, No.21, pp.2088-2094. 
Kolodgie, FD., Burke, AP., Farb, A., Gold, HK., Yuan, J., Narula, J., Finn, AV., \& Virmani, R. (2001). The thin-cap fibroatheroma: a type of vulnerable plaque: the major precursor lesion to acute coronary syndromes. Curr Opin Cardiol, Vol.16, No.5, pp.285-292.

Kolodgie, FD., Gold, HK., Burke, AP., Fowler, DR., Kruth, HS., Weber, DK., Farb, A., Guerrero, LJ., Hayase, M., Kutys, R., Narula, J., Finn, AV., \& Virmani, R. (2003). Intraplaque hemorrhage and progression of coronary atheroma. $N$ Engl $\mathrm{J} \mathrm{Med,}$ Vol.349, No.24, pp.2316-2325.

Kornecki, E., Ehrlich, YH., Egbring, R., Gramse, M., Seitz, R., Eckardt, A., Lukasiewicz, H., \& Niewiarowski, S. (1988). Granulocyte-platelet interactions and platelet fibrinogen receptor exposure. Am J Physiol, Vol.255, No.3 Pt 2, pp.H651-658.

Kulkarni, S., Dopheide, SM., Yap, CL., Ravanat, C., Freund, M., Mangin, P., Heel, KA., Street, A., Harper, IS., Lanza, F., \& Jackson, SP. (2000). A revised model of platelet aggregation. J Clin Invest. Vol.105, No.6, pp.783-791.

Lemkes, BA., Hermanides, J., Devries, JH., Holleman, F., Meijers, JC., \& Hoekstra, JB. (2010). Hyperglycemia: a prothrombotic factor? J Thromb Haemost, Vol.8, No.8, pp.1663-1669.

Loree, HM., Kamm, RD., Atkinson, CM., \& Lee, RT. (1991). Turbulent pressure fluctuations on surface of model vascular stenoses. Am J Physiol, Vol.261, No.3 Pt 2, pp.H644H650.

Loree, HM., Kamm, RD., Stringfellow, RG., \& Lee, RT. (1992). Effects of fibrous cap thickness on peak circumferential stress in model atherosclerotic vessels. Circ Res. Vol.71, No.4, pp.850-858.

Mackman, N. (2004). Role of tissue factor in hemostasis, thrombosis, and vascular development. Arterioscler Thromb Vasc Biol, Vol.24, No.6, pp.1015-1022.

Malek AM, Alper SL, \& Izumo S. (1999). Hemodynamic shear stress and its role in atherosclerosis. JAMA. Vol.282, No.21, pp.2035-2042.

Marzilli, M., Sambuceti, G., Fedele, S., \& L'Abbate A. (2000). Coronary microcirculatory vasoconstriction during ischemia in patients with unstable angina. Am J Coll Cardiol, Vol.35, No.2, pp.327-334.

Massberg, S., Konrad, I., Schürzinger, K., Lorenz, M., Schneider, S., Zohlnhoefer, D., Hoppe, K., Schiemann, M., Kennerknecht, E., Sauer, S., Schulz, C., Kerstan, S., Rudelius, M., Seidl, S., Sorge, F., Langer, H., Peluso, M., Goyal, P., Vestweber, D., Emambokus, NR., Busch, DH., Frampton, J., \& Gawaz M. (2006). Platelets secrete stromal cellderived factor 1alpha and recruit bone marrow-derived progenitor cells to arterial thrombi in vivo. J Exp Med, Vol.203, No.5, pp.1221-1233.

Massberg, S., Grahl, L., von Bruehl, ML., Manukyan, D., Pfeiler, S., Goosmann, C., Brinkmann, V., Lorenz, M., Bidzhekov, K., Khandagale, AB., Konrad, I., Kennerknecht, E., Reges, K., Holdenrieder, S., Braun, S., Reinhardt, C., Spannagl, M., Preissner, KT., \& Engelmann, B. (2010). Reciprocal coupling of coagulation and innate immunity via neutrophil serine proteases. Nat Med, Vol.16, No.8, pp.887-896.

Matsuda, S., Yamashita, A., Sato, Y., Kitajima, S., Koike, T., Sugita, C., Moriguchi-Goto, S., Hatakeyama, K., Takahashi, M., Koshimoto, C., Matsuura, Y., Iwakiri, T., Chen, YE., Fan, J, \& Asada Y. (2011). Human C-reactive protein enhances thrombus formation after neointimal balloon injury in transgenic rabbits. J Thromb Haemost, Vol.9, No.1, pp.201-208.

Miyamoto, S., Ogawa, H., Soejima, H., Takazoe, K., Kajiwara, I., Shimomura, H., Sakamoto, T., Yoshimura, M., Kugiyama, K., Yasue, H., \& Ozaki Y. Enhanced platelet 
aggregation in the coronary circulation after coronary spasm. Thromb Res, Vol.103, No.5, pp.377-386.

Moir, E., Robbie, LA., Bennett, B., \& Booth, NA. (2002). Polymorphonuclear leucocytes have two opposing roles in fibrinolysis. Thromb Haemost. Vol.87, No.6, pp.1006-1010.

Moriguchi-Goto, S., Yamashita, A., Tamura, N., Soejima, K., Takahashi, M., Nakagaki, T., Goto, S., \& Asada, Y. (2009). ADAMTS-13 attenuates thrombus formation on type I collagen surface and disrupted plaques under flow conditions. Atherosclerosis, Vol.203, No.2, pp.409-416.

Muller, JE., Tofler, GH., \& Stone, PH. (1989). Circadian variation and triggers of onset of acute cardiovascular disease. Circulation, Vol.79, No.4, pp.733-743.

Nesbitt, WS., Westein, E., Tovar-Lopez, FJ., Tolouei, E., Mitchell, A., Fu, J., Carberry, J., Fouras, A., Jackson, \& SP. (2009). A shear gradient-dependent platelet aggregation mechanism drives thrombus formation. Nat Med.Vol.15, No.,6 pp.665-673.

Nishihira, K., Yamashita, A., Tanaka, N., Kawamoto, R., Imamura, T., Yamamoto, R., Eto, T., \& Asada, Y. (2006a). Inhibition of 5-hydroxytryptamine receptor prevents occlusive thrombus formation on neointima of the rabbit femoral artery. J Thromb Haemost, Vol.4, No.1, pp.247-255.

Nishihira, K., Imamura, T., Yamashita, A., Hatakeyama, K., Shibata, Y., Nagatomo, Y., Manabe, I., Nagai, R., Kitamura, K., \& Asada, Y. (2006b). Increased expression of interleukin-10 in unstable plaque obtained by directional coronary atherectomy. Eur Heart J. Vol.27, No.2, pp.685-689.

Nishihira, K., Imamura, T., Hatakeyama, K., Yamashita, A., Shibata, Y., Date, H., Manabe, I., Nagai, R., Kitamura, K., \& Asada, Y. (2007). Expression of interleukin-18 in coronary plaque obtained by atherectomy from stable and unstable angina. Thromb Res, Vol.121, No.2, pp.275-279.

Nishihira, K., Yamashita, A., Tanaka, N., Moriguchi-Goto, S., Imamura, T., Ishida, T., Kawashima, S., Yamamoto, R., Kitamura, K., \& Asada, Y. (2008a). Serotonin induces vasoconstriction of smooth muscle cell-rich neointima through 5hydroxytryptamine2A receptor in rabbit femoral arteries. J Thromb Haemost, Vol.6, No.7, pp.1207-1214.

Nishihira, K., Yamashita, A., Imamura, T., Hatakeyama, K., Sato, Y., Nakamura, H., Yodoi, J., Ogawa, H., Kitamura, K., \& Asada, Y. (2008b). Thioredoxin in coronary culprit lesions: possible relationship to oxidative stress and intraplaque hemorrhage. Atherosclerosis, Vol.201, No.2, pp.360-367.

Nishihira, K., Yamashita, A., Ishikawa, T., Hatakeyama, K., Shibata, Y., \& Asada Y. (2010). Composition of thrombi in late drug-eluting stent thrombosis versus de novo acute myocardial infarction. Thromb Res, Vol.126, No.3, pp.254-257.

Okada, K., Ueda, Y., Matsuo, K., Nishio, M., Hirata, A., Kashiwase, K., Asai, M., Nemoto, T., \& Kodama, K. (2011). Frequency and healing of nonculprit coronary artery plaque disruptions in patients with acute myocardial infarction. Am J Cardiol, Vol.107, No.10, pp.1426-1429.

Oshima, S., Yasue, H., Ogawa, H., Okumura, K., \& Matsuyama, K. (1990). Fibrinopeptide A is released into the coronary circulation after coronary spasm. Circulation. Vol.82, No.6, pp.2222-2225.

Owens, AP, 3rd, \& Mackman, N. (2010). Tissue factor and thrombosis: The clot starts here. Thromb Haemost, Vol.104, No.3, pp.432-439.

Østerud, B. (2010). Tissue factor expression in blood cells. Thromb Res. Vol.125, Suppl 1, pp.S31-34. 
Palabrica, T., Lobb, R., Furie, BC., Aronovitz, M., Benjamin, C., Hsu, YM., Sajer, SA., \& Furie, B. (1992). Leukocyte accumulation promoting fibrin deposition is mediated in vivo by P-selectin on adherent platelets. Nature, Vol.359, No.6398, pp.848-851.

Rábai, G., Szilágyi, N., Sótonyi, P., Kovalszky, I., Szabó, L., Machovich, R., \& Kolev, K. (2010). Contribution of neutrophil elastase to the lysis of obliterative thrombi in the context of their platelet and fibrin content. Thromb Res, Vol.126, No.2, pp.e94-101.

Reininger AJ, Bernlochner I, Penz SM, Ravanat C, Smethurst P, Farndale RW, Gachet C, Brandl R, \& Siess W. (2010). A 2-step mechanism of arterial thrombus formation induced by human atherosclerotic plaques. J Am Coll Cardiol. 2010 Vol.55, No.11, pp.1147-1158.

Ridker, PM. (2007). C-reactive protein and the prediction of cardiovascular events among those at intermediate risk: moving an inflammatory hypothesis toward consensus. J Am Coll Cardiol. Vol.49, No.21, pp.2129-2138.

Rosito, GA., D'Agostino, RB., Massaro, J., Lipinska, I., Mittleman, MA., Sutherland, P., Wilson, PW., Levy, D., Muller, JE., \& Tofler, GH. (2004). Association between obesity and a prothrombotic state: the Framingham Offspring Study. Thromb Haemost, Vol.91, No.4, pp.683-689.

Sato, Y., Hatakeyama, K., Yamashita, A., Marutsuka, K., Sumiyoshi, A., \& Asada Y. (2005). Proportion of fibrin and platelets differs in thrombi on ruptured and eroded coronary atherosclerotic plaques in humans. Heart, Vol.91, No.4, pp.526-530.

Sato, Y., Hatakeyama, K., Marutsuka, K., \& Asada Y. (2009). Incidence of asymptomatic coronary thrombosis and plaque disruption: comparison of non-cardiac and cardiac deaths among autopsy cases. Thromb Res, Vol.124, No.1, pp.19-23.

Schwartz, RS., Burke, A., Farb, A., Kaye, D., Lesser, JR., Henry, TD., \& Virmani, R. (2009). Microemboli and microvascular obstruction in acute coronary thrombosis and sudden coronary death: relation to epicardial plaque histopathology. J Am Coll Cardiol, Vol.54, No.23, pp.2167-2173.

Shah, PK. (2003). Mechanisms of plaque vulnerability and rupture. J Am Coll Cardiol, Vol.41, No.4 Suppl S, pp.15S-22S.

Shida, Y., Nishio, K., Sugimoto, M., Mizuno, T., Hamada, M., Kato, S., Matsumoto, M., Okuchi, K., Fujimura, Y., \& Yoshioka, A. (2008). Functional imaging of sheardependent activity of ADAMTS13 in regulating mural thrombus growth under whole blood flow conditions. Blood. Vol.111, No.3, pp.1295-1298.

Singh, N., Gemmell, CH., Daly, PA., \& Yeo, EL. (1995). Elevated platelet-derived microparticle levels during unstable angina. Can J Cardiol, Vol.11, No.11, pp.1015-1021.

Stary, HC., Chandler, AB., Dinsmore, RE., Fuster, V., Glagov, S., Insull, W. Jr., Rosenfeld, ME., Schwartz, CJ., Wagner, WD., \& Wissler, RW. (1995). A definition of advanced types of atherosclerotic lesions and a histological classification of atherosclerosis. A report from the Committee on Vascular Lesions of the Council on Arteriosclerosis, American Heart Association. Arterioscler Thromb Vasc Biol, Vol.15, No.9, pp.1512-1531.

Sumi, T., Yamashita, A., Matsuda, S., Goto, S., Nishihira, K., Furukoji, E., Sugimura, H., Kawahara, H., Imamura, T., Kitamura, K., Tamura, S., \& Asada, Y. (2010). Disturbed blood flow induces erosive injury to smooth muscle cell-rich neointima and promotes thrombus formation in rabbit femoral artery. J Thromb Haemost. Vol.8, No.6, pp.1394-1402.

Sun, H., Koike, T., Ichikawa, T., Hatakeyama, K., Shiomi, M., Zhang, B., Kitajima, S., Morimoto, M., Watanabe, T., Asada, Y., Chen, YE., \& Fan, J. (2005). C-reactive 
protein in atherosclerotic lesions: its origin and pathophysiological significance. Am J Pathol, Vol.167, No.4, pp.1139-1148.

Topol, EJ., \& Yadav, JS. (2003). Recognition of the importance of embolization in atherosclerotic vascular disease. Circulation. Vol.101, No.5, pp.570-580.

Vandendries, ER., Furie, BC., \& Furie, B. (2004). Role of P-selectin and PSGL-1 in coagulation and thrombosis. Thromb Haemost. Vol.92, No.3, pp.459-466.

Virmani, R., Burke, AP., Kolodgie, FD., \& Farb, A. (2003). Pathology of the thin-cap fibroatheroma: a type of vulnerable plaque. J Interv Cardiol. Vol.16.No.3, pp.267-272.

Virmani, R., Kolodgie, FD., Burke, AP., Farb, A., \& Schwartz, SM. (2000). Lessons from sudden coronary death: a comprehensive morphological classification scheme for atherosclerotic lesions. Arterioscler Thromb Vasc Biol, Vol.20, No.5, pp.1262-1275.

Waldo, SW., Li, Y., Buono, C., Zhao, B., Billings, EM., Chang, J., \& Kruth, HS. (2008). Heterogeneity of human macrophages in culture and in atherosclerotic plaques. Am J Pathol, Vol.172, No.4, pp.1112-1126.

Wang, L., Miller, C., Swarthout, RF., Rao, M., Mackman, N., \& Taubman, MB. (2009). Vascular smooth muscle-derived tissue factor is critical for arterial thrombosis after ferric chloride-induced injury. Blood. Vol.113, No.3, pp.705-713.

Wilcox, JN., Smith, KM., Schwartz, SM., \& Gordon D. (1989). Localization of tissue factor in the normal vessel wall and in the atherosclerotic plaque. Proc Natl Acad Sci U S A, Vol.86, No.8, pp.2839-2843.

Yamashita, A., Asada, Y., Sugimura, H., Yamamoto, H., Marutsuka, K., Hatakeyama, K., Tamura, S., Ikeda, Y., \& Sumiyoshi, A. (2003). Contribution of von Willebrand factor to thrombus formation on neointima of rabbit stenotic iliac artery under high blood-flow velocity. Arterioscler Thromb Vasc Biol, Vol.23, No.6, pp.1105-1110.

Yamashita, A., Furukoji, E., Marutsuka, K., Hatakeyama, K., Yamamoto, H., Tamura, S., Ikeda, Y., Sumiyoshi, A., \& Asada, Y. (2004). Increased vascular wall thrombogenicity combined with reduced blood flow promotes occlusive thrombus formation in rabbit femoral artery. Arterioscler Thromb Vasc Biol, Vol.24, No.12, pp.2420-2424.

Yamashita, A., Sumi, T., Goto, S., Hoshiba, Y., Nishihira, K., \& Kawamoto R, et al. (2006a). Detection of von Willebrand factor and tissue factor in platelets-fibrin rich coronary thrombi in acute myocardial infarction. Am J Cardiol, Vol.97, No.1, pp.26-28.

Yamashita, A., Nishihira, K., Kitazawa, T., Yoshihashi, K., Soeda, T., Esaki, K., Imamura, T., Hattori, K., \& Asada, Y. (2006b). Factor XI contributes to thrombus propagation on injured neointima of the rabbit iliac artery. J Thromb Haemost, Vol.4, No.7, pp.14961501.

Yamashita, A., Matsuda, S., Matsumoto, T., Moriguchi-Goto, S., Takahashi, M., Sugita, C., Sumi, T., Imamura, T., Shima, M., Kitamura, K., \& Asada, Y. (2009). Thrombin generation by intimal tissue factor contributes to thrombus formation on macrophage-rich neointima but not normal intima of hyperlipidemic rabbits. Atherosclerosis. Vol.206, No.2, pp.418-426.

Zeng, B., Bruce, D., Kril, J., Ploplis, V., Freedman, B., \& Brieger, D. (2002). Influence of plasminogen deficiency on the contribution of polymorphonuclear leucocytes to fibrin/ogenolysis: studies in plasminogen knock-out mice. Thromb Haemost. Vol.88, No.5, pp.805-810. 


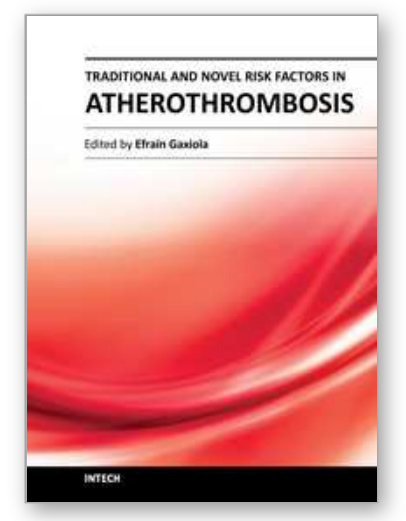

\author{
Traditional and Novel Risk Factors in Atherothrombosis \\ Edited by Dr. Efrain Gaxiola
}

ISBN 978-953-51-0561-9

Hard cover, 140 pages

Publisher InTech

Published online 20, April, 2012

Published in print edition April, 2012

Atherothrombosis has reached pandemic proportions worldwide. It is the underlying condition that results in events leading to myocardial infarction, ischemic stroke and vascular death. As such, it is the leading cause of death worldwide manifested mainly as cardiovascular/cerebrovascular death. The complex and intimate relationship between atherothrombosis and traditional and novel risk factors is discussed in the following chapters of Traditional and Novel Risk Factors in Atherothrombosis - from basic science to clinical and therapeutic concerns. Beginning with pathology and pathophysiology of atherothrombosis, plaque rupture/disruption, this book continues with molecular, biochemical, inflammatory, cellular aspects and finally analyzes several aspects of clinical pharmacology.

\title{
How to reference
}

In order to correctly reference this scholarly work, feel free to copy and paste the following:

Atsushi Yamashita and Yujiro Asada (2012). Pathology and Pathophysiology of Atherothrombosis: Virchow's Triad Revisited, Traditional and Novel Risk Factors in Atherothrombosis, Dr. Efrain Gaxiola (Ed.), ISBN: 978953-51-0561-9, InTech, Available from: http://www.intechopen.com/books/traditional-and-novel-risk-factors-inatherothrombosis/pathology-and-pathophysiology-of-atherothrombosis-virchow-s-triad-revisited-

\section{INTECH}

open science | open minds

\section{InTech Europe}

University Campus STeP Ri

Slavka Krautzeka 83/A

51000 Rijeka, Croatia

Phone: +385 (51) 770447

Fax: +385 (51) 686166

www.intechopen.com

\section{InTech China}

Unit 405, Office Block, Hotel Equatorial Shanghai

No.65, Yan An Road (West), Shanghai, 200040, China

中国上海市延安西路65号上海国际贵都大饭店办公楼 405 单元

Phone: +86-21-62489820

Fax: +86-21-62489821 
(C) 2012 The Author(s). Licensee IntechOpen. This is an open access article distributed under the terms of the Creative Commons Attribution 3.0 License, which permits unrestricted use, distribution, and reproduction in any medium, provided the original work is properly cited. 